\title{
GESTÃO ESCOLAR A SUA IMPORTÂNCIA NO COTIDIANO DA EDUCAÇÃO INFANTIL DO CAMPO
}

\author{
Liliane Rangelia Alves de Queiroz; ${ }^{1}$ Jacqueline Nunes Araujo².
}

1. Bolsista FAPESB. Graduanda em Licenciatura em Pedagogia, Universidade Estadual de Feira de Santana, e-mail: lili.alves15@ hotmail.com

2. Orientador, Departamento de Educação, Universidade Estadual de Feira de Santana, e-mail: jacnunes3@gmail.com

PALAVRAS-CHAVE: Gestão Escolar; Educação do Campo; Espaço Infantil.

\section{INTRODUÇÃO}

As escolas do campo enfrentam inúmeras dificuldades, que vão desde a precariedade de no que diz respeito à infraestrutura física, quanto ao descaso e a má qualidade no ensino ofertado, como diz Fernandes é preciso "ver o campo como parte do mundo e não como aquilo que sobra além das cidades" (FERNANDES, 2002, p. 62).

Lugar onde as crianças costumam conhecer o trabalho desde muito cedo, a educação infantil no campo não é uma etapa da educação muito valorizada, mesmo que existam leis que garantam tais medidas. Está previsto nas Diretrizes Curriculares Nacionais Para a Educação Infantil, que:

Na observância das Diretrizes, a proposta pedagógica das instituições de Educação Infantil deve garantir que elas cumpram plenamente sua função sociopolítica e pedagógica: Oferecendo condições e recursos para que as crianças usufruam seus direitos civis, humanos e sociais; Assumindo a responsabilidade de compartilhar e complementar a educação e cuidado das crianças com as famílias; Possibilitando tanto a convivência entre crianças e entre adultos e crianças quanto à ampliação de saberes e conhecimentos de diferentes naturezas; Promovendo a igualdade de oportunidades educacionais entre as crianças de diferentes classes sociais no que se refere ao acesso a bens culturais e às possibilidades de vivência da infância; Construindo novas formas de sociabilidade e de subjetividade comprometidas com a ludicidade, a democracia, a sustentabilidade do planeta e com o rompimento de relações de dominação etária, socioeconômica, étnico racial, de gênero, regional, linguística e religiosa. (p.17). 
Porém sabemos que esses direitos nem sempre são garantidos. A educação rural no Brasil foi algo que sempre esteve em segundo plano. Havia um pensamento que 'gente da roça não necessita de escola'. Furtado [2003 ou 2004]. Conceitos estes que através de muitas lutas sociais vem sendo rompidos.

Mas para que haja uma educação que propicie melhores condições aos povos do campo, seja na educação infantil ou não é necessário que a gestão da escola pense e propicie no ambiente educacional políticas que sejam apropriadas para os mesmos, pensando e agindo como uma gestão democrática, e levando em conta onde vivem, suas bagagens e vivências, como diz ARROYO é importante que as políticas:

Parta dos diferentes sujeitos do campo, do seu contexto, sua cultura e seus valores, sua maneira de ver e se relacionar com o tempo, a terra, com o meio ambiente, seus modos de organizar a família, o trabalho, seus modos de ser homem, mulher, criança, adolescente, jovem, adulto ou idoso; de seus modos de ser e se formar como humanos. Fazer do povo do campo e de seus processos de formação o ponto de partida para a formulação de políticas públicas educativas significa garantir o caráter popular dessas políticas e sua articulação com o projeto de país e de campo. (ARROYO et al, 2004, p. 14-15).

Partindo do ponto de que a gestão da escola é responsável por analisar, elaborar e lançar propostas que contemplem toda a comunidade escolar é preciso que se pense em uma gestão democrática no sentido mais amplo da palavra. Como diz Vallim, "ser democrático é respeitar os ritmos, as dificuldades, a linguagem e a cultura de cada um, em suas diferenças. As propostas não podem ser impostas. Precisam ser construídas e reconstruídas com as pessoas envolvidas" (Celso Vallim, 2004).

A pesquisa tem como objetivo analisar em que medida o trabalho do gestor escolar contribuí com práticas democráticas no âmbito das escolas do campo. Assim como verificar qual é o tipo de gestão efetiva na escola; Analisar as atribuições do gestor e o modelo de gestão vivido na escola de educação do campo; Descrever e analisar os processos meios e estratégias de articulação do gestor na escola do campo para promoção de práticas efetivamente democráticas.

\section{METODOLOGIA}


As atividades de pesquisa envolveram: levantamento, compilação e análise da bibliografia existente sobre a temática; levantamento e pesquisa documental (pareceres, portarias, resoluções) sobre a gestão escolar na educação do campo nas escolas que oferecem a primeira etapa da educação básica, a educação infantil; aplicação de entrevista com a gestão escolar.

A pesquisa consiste em levantamento documental das ações desenvolvidas, do gestor das escolas bem como investigará os efeitos na gestão da educação infantil do campo no âmbito dos distritos pesquisados. A investigação será também por meio de questionários sobre: o perfil dos gestores, recursos humanos e materiais; a formação continuada dos gestores e coordenadores.

Para atingir os objetivos propostos dessa pesquisa foram realizadas análises documentais e bibliográficas e também entrevistas com a gestora de uma unidade escolar, com o intuito de analisar as características da gestão adotada dentro da escola. A pesquisa pretende analisar a ocorrência de mudanças nos modos de gestão dos sistemas de ensino por meio da verificação da organização e funcionamento das secretárias e/ou órgãos de gestão municipal da educação.

\section{ANÁLISE E DISCUSSÃO DOS RESULTADOS}

Á Luz da literatura pesquisada e observação realisada percebeu-se que, a gestão escolar é um fator crucial no desenvolvimento e na qualidade da educação das crianças, e isso se faz ainda mais importante quanto falamos das escolas localizadas nas zonas rurais. Através da observação na escola pesquisada, pudemos perceber o quanto a gestão escolar está empenhada em fornecer para as crianças uma educação digna, especifica e de qualidade. A equipe gestora busca aproximar as crianças desde muito cedo a cultura e as práticas exercidas no campo, valorizando assim a cultura e os costumes dos povos das zonas rurais, o objetivo principal da gestão é fazer com que os alunos se desenvolvam e tenham orgulho de sua própria historia.

É bastante satisfatório perceber a existem escolas que sem empenham na promoção e construção de uma educação do campo de qualidade, e mais satisfatório ainda é poder conhecer uma escola baseada nesses princípios de perto, sua rotina, suas buscas diárias e suas conquistas. 
Diante do exposto, pudemos comprovar o quanto a presença e atuação de uma gestão efetivamente democrática, só tem a agregar dentro do âmbito escolar, em uma escola do campo o papel da gestão torna-se ainda mais essencial.

Promover a valorização da cultura do campo desde a educação infantil é crucial para que as crianças se desenvolvam sabendo de onde elas vêm, entendendo desde cedo o valor da sua cultura.

\section{REFERENCIAS}

ARROYO, M. G. Formação de Educadores e Educadoras do Campo. Brasília: MEC, 2004

BRASIL. Lei de Diretrizes e Bases da Educação Nacional. Lei número 9394, 20 de dezembro de 1996.

FERNANDES, Bernardo Mançano. Diretrizes de uma Caminhada. In: KOLLING. Edgar Jorge. CERIOLI, Paulo Ricardo. CALDART, Roseli Salete (orgs.). Educação do Campo: identidade e políticas públicas - Coleção Por Uma Educação do Campo, n. ${ }^{\circ}$ 4. Brasília: Articulação Nacional Por Uma Educação do Campo, 2002.

LUCE, Maria Beatriz. MEDEIROS, Isabel Letícia Pedroso de. "Gestão democrática na e da educação: concepções e vivências" IN: LUCE, Maria Beatriz. MEDEIROS, Isabel Letícia Pedroso de (org.). Gestão escolar democrática: concepções e vivências. Porto Alegre: UFRGS Editora, 2006.

VALlin, Celso. Poder e Democracia na Escola. Artigo Publicado no Curso Gestão Escolar e Tecnologias (2004). 